\title{
Minimizing bleeding risk in patients receiving direct oral anticoagulants for stroke prevention
}

\author{
Jeffrey Steven Habert \\ Department of Family and Community \\ Medicine, University of Toronto, \\ Toronto, ON, Canada
}

This article was published in the following Dove Press journal:

International Journal of General Medicine

II October 2016

Number of times this article has been viewed

\begin{abstract}
Many primary care physicians are wary about using direct oral anticoagulants (DOACs) in patients with nonvalvular atrial fibrillation (AF). Factors such as comorbidities, concomitant medications, and alcohol misuse increase concerns over bleeding risk, especially in elderly and frail patients with AF. This article discusses strategies to minimize the risk of major bleeding events in patients with AF who may benefit from oral anticoagulant therapy for stroke prevention. The potential benefits of the DOACs compared with vitamin K antagonists, in terms of a lower risk of intracranial hemorrhage, are discussed, together with the identification of reversible risk factors for bleeding and correct dose selection of the DOACs based on a patient's characteristics and concomitant medications. Current bleeding management strategies, including the new reversal agents for the DOACs and the prevention of bleeding during preoperative anticoagulation treatment, in addition to health care resource use associated with anticoagulation treatment and bleeding, are also discussed. Implementing a structured approach at an individual patient level will minimize the overall risk of bleeding and should increase physician confidence in using the DOACs for stroke prevention in their patients with nonvalvular AF.
\end{abstract}

Keywords: anticoagulants, atrial fibrillation, bleeding, primary care

\section{Introduction}

Atrial fibrillation (AF), the most common cardiac arrhythmia, is associated with a fivefold increase in the risk of stroke., ${ }^{1,2}$ At least one in five strokes occurs in patients with $\mathrm{AF}$, and these strokes are twice as likely to have fatal or disabling consequences (30\%-50\% 1-year mortality rates). ${ }^{1,3-6}$ The risk of stroke in patients with nonvalvular AF can be reduced effectively with anticoagulants, such as vitamin K antagonists (VKAs; eg, warfarin) or direct oral anticoagulants (DOACs; eg, apixaban, dabigatran, edoxaban, and rivaroxaban), ${ }^{7,8}$ although the benefits of therapy should always be balanced against the increased risk of bleeding associated with all anticoagulants. ${ }^{9}$ Nevertheless, physicians should remember that the principal goal of anticoagulation in patients with $\mathrm{AF}$ is the prevention of stroke, and they should be mindful of the patient's perspective on stroke and bleeding events; many patients view their reduced quality of life after major stroke as tantamount to or worse than death, ${ }^{10}$ and available data indicate that patients with AF place more value on the avoidance of stroke than the avoidance of bleeding, compared with physicians who treat patients with AF. ${ }^{11}$ The phrase "we can replace blood, but we cannot replace brain" serves as a useful reminder for physicians that an increase in the risk of bleeding may be an acceptable side effect of achieving this goal, and that most bleeding events can be managed easily using standard methods. ${ }^{12}$

Correspondence: Jeffrey Steven Habert Department of Family and Community Medicine, University of Toronto, 2062900 Steeles Avenue East, Thornhill, ON, L3T4XI, Canada

Mob +I 9058816667

Email jhabert@rogers.com 
The risks of serious bleeding (ie, intracranial hemorrhage $[\mathrm{ICH}]$ or other critical site bleeding) that are associated with all anticoagulants are of concern to physicians. ${ }^{13,14}$ This review aims to address these concerns through discussion of the potential benefits offered by the DOACs in terms of improved safety profiles compared with VKAs. The use of bleeding risk scores to identify and manage a patient's reversible risk factors for bleeding (separate from the general risk common to all anticoagulants) is explored and consideration is given to correct DOAC dose selection, which - together with correction of reversible risk factors for bleeding - can reduce the risk of DOAC-associated bleeding. Finally, the different approaches and agents used in the prevention and management of bleeding, including the recently developed DOAC reversal agents, are discussed. Using this personalized approach to minimize a patient's overall risk of bleeding should help to instill confidence among physicians in the use of the DOACs for stroke prevention in patients with nonvalvular AF.

\section{Safety of the DOACs for the prevention of stroke in patients with nonvalvular AF}

The safety and efficacy of the DOACs (rivaroxaban, dabigatran, apixaban, and edoxaban) are well established from large Phase III studies in patients with nonvalvular AF. ${ }^{15-18}$ The DOACs were superior to or as effective as warfarin for the prevention of stroke and systemic embolism, and rates of major bleeding were similar or lower in DOAC-treated patients compared with those in warfarin-treated patients.
Importantly, all four DOACs were associated with significantly lower incidences of ICH and numerically lower or significantly lower rates of fatal bleeding (Table 1). ${ }^{15-21}$ However, rivaroxaban and the higher tested doses of dabigatran (150 mg twice daily [bid]) and edoxaban (60 mg once daily [od]) were all associated with significantly higher rates of major gastrointestinal (GI) bleeding..$^{17,19,22}$

Meta-analysis, pooling data from the four trials, reinforces the favorable benefit-risk profile of the DOACs compared with warfarin; importantly, the DOACs were associated with a $50 \%$ reduction in the risk of $\mathrm{ICH}$, the most feared type of bleeding event. ${ }^{23}$ Although the overall rates of major bleeding in DOAC-treated patients were similar to those seen in warfarin-treated patients, the DOACs were associated with an increased risk of GI bleeding in this meta-analysis. ${ }^{23}$ Efficacy and safety outcomes for the DOACs were found to be consistent across a wide range of patients, including the elderly (aged $\geq 75$ years), those with mild or moderate renal impairment, and those at a high risk of stroke. ${ }^{23}$

Physicians are often concerned that patients enrolled in Phase III clinical trials are not representative of those they see daily in clinical practice. Encouragingly, accumulating real-world data on the use of the DOACs (predominantly available for rivaroxaban and dabigatran) for stroke prevention in patients with AF suggest that their safety profiles in unselected patients seen in routine care are consistent with those observed in the Phase III studies. For example, the recently published results from XANTUS $(\mathrm{N}=6,784)$, the first completed prospective, multinational (excluding

Table I Key safety outcomes in the Phase III clinical trials comparing the use of DOACs with warfarin for stroke prevention in patients with nonvalvular atrial fibrillation

\begin{tabular}{|c|c|c|c|c|c|c|}
\hline Parameter & \multicolumn{2}{|c|}{ Dabigatran (RE-LY) ${ }^{16,19-21}$} & \begin{tabular}{|l} 
Rivaroxaban \\
(ROCKET AF) $^{15,22,70}$
\end{tabular} & $\begin{array}{l}\text { Apixaban } \\
\text { (ARISTOTLE) }^{18}\end{array}$ & \multicolumn{2}{|c|}{$\begin{array}{l}\text { Edoxaban (ENGAGE AF- } \\
\text { TIMI)17 }\end{array}$} \\
\hline Patients randomized & \multicolumn{2}{|l|}{18,113} & 14,264 & 18,201 & \multicolumn{2}{|l|}{21,105} \\
\hline Comparator & \multicolumn{6}{|c|}{ Dose-adjusted warfarin (target INR 2.0-3.0) } \\
\hline Doses tested & $110 \mathrm{mg}$ bid & $150 \mathrm{mg}$ bid & $20 \mathrm{mg}^{\circ} \mathrm{d}^{\mathrm{a}}$ & $5 \mathrm{mg} \mathrm{bid}^{\mathrm{b}}$ & $30 \mathrm{mg} \mathrm{od}^{\mathrm{c}}$ & $60 \mathrm{mg} \mathrm{od}^{\mathrm{c}}$ \\
\hline $\begin{array}{l}\text { Patients eligible for } \\
\text { reduced dose }\end{array}$ & NA & NA & $2,950(20.7 \%)$ & $831(4.6 \%)$ & \multicolumn{2}{|c|}{$\begin{array}{l}5,330(25.3 \%) \text { at randomization; } \\
7.1 \% \text { after randomization }\end{array}$} \\
\hline \multicolumn{7}{|c|}{ Major bleeding outcomes (DOAC vs warfarin; \% per year) } \\
\hline Major bleeding & $\begin{array}{l}2.92 \text { vs } 3.61 ; \\
P=0.003\end{array}$ & $\begin{array}{l}3.40 \text { vs } 3.61 ; \\
P=0.4 I\end{array}$ & 3.6 vs $3.4 ; P=0.58$ & 2.13 vs $3.09 ; P<0.001$ & $\begin{array}{l}\text { I.6I vs } 3.43 \\
P<0.001\end{array}$ & $\begin{array}{l}2.75 \text { vs } 3.43 \\
P<0.001\end{array}$ \\
\hline Fatal bleeding & $\begin{array}{l}0.19 \text { vs } 0.33 ; \\
P=0.039\end{array}$ & $\begin{array}{l}0.23 \text { vs } 0.33 ; \\
P=0.15\end{array}$ & 0.2 vs $0.5 ; P=0.003$ & NR (34 vs 55 patients) & $\begin{array}{l}0.13 \text { vs } 0.38 \\
P<0.001\end{array}$ & $\begin{array}{l}0.2 I \text { vs } 0.38 \\
P=0.006\end{array}$ \\
\hline $\mathrm{ICH}$ & $\begin{array}{l}0.23 \text { vs } 0.76 \\
P<0.001\end{array}$ & $\begin{array}{l}0.32 \text { vs } 0.76 \\
P<0.00 \text { I }\end{array}$ & 0.5 vs $0.7 ; P=0.02$ & 0.33 vs $0.80 ; P<0.001$ & $\begin{array}{l}0.26 \text { vs } 0.85 \\
P<0.00 \text { I }\end{array}$ & $\begin{array}{l}0.39 \text { vs } 0.85 \\
P<0.00 \text { I }\end{array}$ \\
\hline Major GI bleeding & $\begin{array}{l}\text { I. } .15 \text { vs } 1.07 ; \\
P=0.52\end{array}$ & $\begin{array}{l}\text { I.56 vs } 1.07 ; \\
P=0.00 \mathrm{I}\end{array}$ & 2.00 vs I. $24 ; P<0.000$ I & 0.76 vs $0.86 ; P=0.37$ & $\begin{array}{l}0.82 \text { vs } 1.23 \\
P<0.00 \text { I }\end{array}$ & $\begin{array}{l}I .5 I \text { vs } I .23 \\
P=0.03\end{array}$ \\
\hline
\end{tabular}

Notes: a $15 \mathrm{mg}$ od for patients with $\mathrm{CrCl} 30-49 \mathrm{~mL} / \mathrm{min}$ at randomization; ${ }^{\mathrm{b}} 2.5 \mathrm{mg}$ bid for patients with $\geq 2$ of: weight $\leq 60 \mathrm{~kg}$, age $\geq 80$ years, or serum creatinine $\geq 1.5 \mathrm{mg} / \mathrm{dL}$ at randomization; and 'dose was halved if any of the following characteristics were present at randomization or during study: $\mathrm{CrCl} 30-50 \mathrm{~mL} / \mathrm{min}$, weight $\leq 60 \mathrm{~kg}$, or concomitant use of potent P-glycoprotein inhibitors (verapamil, quinidine, or dronedarone).

Abbreviations: bid, twice daily; $\mathrm{CrCl}$, creatinine clearance; DOAC, direct oral anticoagulant; $\mathrm{GI}$, gastrointestinal; ICH, intracranial hemorrhage; INR, international normalized ratio; NA, not applicable; NR, not reported; od, once daily. 
the United States), noninterventional study of a DOAC in patients with nonvalvular AF, show that rivaroxaban is associated with low rates of major bleeding (2.1\%/year), including ICH (0.4\%/year) and major GI bleeding $(0.9 \%$ / year), as well as a low risk of stroke (0.7\%/year). ${ }^{24}$ These findings are supported by data from a United States postmarketing surveillance study $(\mathrm{N}=27,467)$; retrospective analysis of electronic medical records, using an algorithm that allows identification of major bleeding events resulting in hospitalization, showed that the rate of major bleeding in rivaroxaban-treated patients was $2.9 \%$ per year. ${ }^{25}$ In the case of dabigatran, several large, retrospective, propensity-matched, or adjusted analyses suggest that the relative safety of dabigatran versus VKAs is similar to that observed in the Phase III RE-LY trial, including superior or noninferior protection from stroke and systemic embolism, significantly reduced rates of $\mathrm{ICH}$, and similar or higher rates of GI bleeding. ${ }^{26-30}$ Because of the increased risk of GI bleeding identified in DOAC-treated patients in the Phase III ROCKET AF and RE-LY studies, two recently published retrospective studies have focused specifically on this outcome; reassuringly, GI bleeding rates between warfarin- and both rivaroxaban- and dabigatran-treated patients were similar in both studies, although elderly ( $\geq 75$ years old) DOAC-treated patients were shown to be at higher risk. ${ }^{31,32}$

\section{Using risk scores to identify patients at increased risk of bleeding}

Bleeding at critical sites is a major concern, but such concerns should never preclude the use of an oral anticoagulant; instead, physicians should focus on modifying/minimizing existing risk factors for bleeding. Several validated scoring systems are available that can be used to assess risk of bleeding in patients with AF, including the HAS-BLED score, the ATRIA score, and the recently described ORBIT bleeding score, all of which include advanced age, impaired renal function, bleeding history, and anemia as risk factors for bleeding (Table 2). ${ }^{33-35}$ Owing to its simplicity and its inclusion of modifiable risk factors (eg, uncontrolled hypertension, concurrent antiplatelet agents or nonsteroidal anti-inflammatory drugs, harmful alcohol consumption, and labile international normalized ratios for patients on VKAs), European and UK guidelines recommend the use of the HAS-BLED score to assess the risk of bleeding in patients with AF. ${ }^{36,37}$ However, data from real-world practice indicate that approximately half of physicians estimate or guess bleeding risk in their patients with AF without using any risk scores; furthermore, in one-third of cases physician-estimated bleeding risk did not align with HAS-BLED-estimated bleeding risk, with one-quarter of physicians overestimating the risk of bleeding. ${ }^{38}$ Patients with a high risk of bleeding can be identified by a HASBLED score of $\geq 3$; however, a patient's bleeding risk score should not be used to preclude the use of anticoagulants. Instead, in most cases, an anticoagulant should be used with appropriate caution - regular follow-up appointments should be scheduled and actions taken to resolve any modifiable risk factors contributing to the patient's elevated risk, as discussed further in the following section. ${ }^{36}$ Very rarely will an individual's risk of bleeding greatly outweigh their risk of stroke, in which case the benefit-risk ratio may favor no thromboprophylaxis. ${ }^{39}$

Table 2 Bleeding risk scores validated for use in patients with nonvalvular atrial fibrillation

\begin{tabular}{|c|c|c|c|c|c|}
\hline \multicolumn{2}{|l|}{ HAS-BLED ${ }^{33}$} & \multicolumn{2}{|l|}{ ATRIA $^{34}$} & \multicolumn{2}{|l|}{ ORBIT $^{35}$} \\
\hline $\begin{array}{l}\text { Hypertension - uncontrolled (>160 mmHg } \\
\text { systolic) }\end{array}$ & I & Anemia $^{a}$ & 3 & Older age ( $\geq 75$ years old) & I \\
\hline $\begin{array}{l}\text { Abnormal renal function }(\mathrm{SCr} \geq 200 \mu \mathrm{mol} / \mathrm{L} \\
\text { or dialysis or transplantation) or abnormal } \\
\text { hepatic function }^{\mathrm{b}}\end{array}$ & I or 2 & $\begin{array}{l}\text { Severe renal disease (eGFR } \\
<30 \mathrm{~mL} / \mathrm{min} \text { or dialysis) }\end{array}$ & 3 & $\begin{array}{l}\text { Reduced hemoglobin }{ }^{\mathrm{a}} \text {, reduced } \\
\text { hematocritc }^{\text {, }} \text { or anemia }\end{array}$ & 2 \\
\hline Stroke history & $\mathrm{I}$ & $\geq 75$ years old & 2 & Bleeding history & 2 \\
\hline $\begin{array}{l}\text { Bleeding history or predisposition to } \\
\text { bleeding (eg, anemia and bleeding diathesis) }\end{array}$ & 1 & Any prior hemorrhage & 1 & $\begin{array}{l}\text { Insufficient kidney function } \\
\left(\mathrm{eGFR}<60 \mathrm{mg} / \mathrm{dL} / 1.73 \mathrm{~m}^{2}\right)\end{array}$ & $\mathrm{I}$ \\
\hline Labile INRs & 1 & Diagnosed hypertension & 1 & Treatment with antiplatelets & $\mathrm{I}$ \\
\hline Elderly (>65 years old) & 1 & - & - & - & - \\
\hline $\begin{array}{l}\text { Drugs or alcohol (antiplatelet agents or } \\
\text { NSAIDs; alcohol } \geq 8 \text { units per week) }\end{array}$ & I or 2 & - & - & - & - \\
\hline Maximum score & 9 & Maximum score & 10 & Maximum score & 7 \\
\hline
\end{tabular}

Notes: Potentially modifiable bleeding risk factors are shown with green shading; criteria that may mandate the use of a reduced-dose DOAC to reduce bleeding risk are shown with orange shading; in the case of older patients, dose reductions may only be mandated in patients $\geq 80$ years old on certain DOACs. ${ }^{a} \mathrm{Hemog}$ lobin $<13$ g/dL in men and $<12 \mathrm{~g} / \mathrm{dL}$ in women; ${ }^{b}$ chronic hepatic disease (eg, cirrhosis) or biochemical evidence of significant hepatic derangement (eg, bilirubin $>2 \times$ upper limit of normal, in association with aspartate aminotransferase/alanine aminotransferase/alkaline phosphatase $>3 \times$ upper limit normal); and ${ }^{\mathrm{c}}<40 \%$ for men and $<36 \%$ for women.

Abbreviations: DOAC, direct oral anticoagulant; eGFR, estimated glomerular filtration rate; INR, international normalized ratio; NSAID, nonsteroidal anti-inflammatory drug; SCr, serum creatinine. 


\section{Minimizing existing risk factors for bleeding in patients receiving DOACs for stroke prevention}

Reversible risk factors for bleeding, including concomitant medications, comorbidities (eg, hypertension), and alcohol misuse, can be corrected. ${ }^{40}$ Most patients diagnosed with nonvalvular AF are elderly with multiple comorbidities; the increased risk of bleeding associated with comorbidities (such as hypertension and diabetes), polypharmacy, and falls can complicate the care of these patients and make bleeding management difficult. However, many strategies for the management of reversible bleeding risk factors are available within primary care to help lower the overall risk. If physicians refocus on managing modifiable risk factors for bleeding, outside of the general risk associated with anticoagulant use, the risks of bleeding can be minimized. Actions to correct bleeding risk factors in patients receiving the DOACs may include controlling blood pressure, reducing alcohol intake, and minimizing concomitant use of drugs affecting hemostasis or increasing the risk of bleeding (eg, antiplatelet agents, including acetylsalicylic acid and nonsteroidal anti-inflammatory drugs) and drugs inhibiting the P-glycoprotein and cytochrome P450 3A4 pathways that may lead to increased DOAC plasma concentrations (Table 3 ). ${ }^{36}$

Although not identified as a bleeding risk factor per se, many physicians may be reluctant to prescribe an anticoagulant in frail, elderly patients perceived as being at risk of falling. However, it has been estimated that an elderly patient with a $6 \%$ annual risk of stroke (ie, a $\mathrm{CHA}_{2} \mathrm{DS}_{2}$-VASc score of between 4 and 5) would have to fall 295 times a year for the risks of warfarin therapy to outweigh the potential benefits. ${ }^{41}$ These data are supported by real-world evidence showing that, although patients at risk of falls have a higher incidence of $\mathrm{ICH}$, the benefits of warfarin significantly outweigh the risks in patients with a $\mathrm{CHADS}_{2}$ score of $\geq 2 .{ }^{42}$ Therefore, a potential danger of subdural hematoma as a consequence of a fall should not preclude the use of an oral anticoagulant; ${ }^{37}$ instead, steps should be taken to minimize the risk of falls, such as correction of visual impairment and use of mobility aids (Table 3 ).

Table 3 Reversible risk factors and management strategies for bleeding in patients with AF receiving DOACs

\begin{tabular}{|c|c|}
\hline Reversible risk factors for bleeding in patients with AF & Management \\
\hline \multicolumn{2}{|l|}{ Hypertension } \\
\hline $\begin{array}{l}\text { A systolic blood pressure of } \geq 140 \mathrm{mmHg} \text { is associated with an increase in the } \\
\text { risk of both hemorrhagic and ischemic stroke among patients with } \mathrm{AF}^{40}\end{array}$ & $\begin{array}{l}\text { - Regular monitoring for patients with a history of hypertension } \\
\text { - Adequate control of blood pressure to the recommended level }\end{array}$ \\
\hline \multicolumn{2}{|l|}{ Diabetes } \\
\hline $\begin{array}{l}\text { Diabetes is associated with an increased risk of bleeding in patients with AF } \\
\text { receiving anticoagulation therapy }{ }^{71}\end{array}$ & $\begin{array}{l}\text { - Review medication and dosing regularly to ensure good } \\
\text { glycemic control }\end{array}$ \\
\hline \multicolumn{2}{|l|}{ Gastrointestinal bleeding } \\
\hline $\begin{array}{l}\text { Risk of gastrointestinal bleeding is increased: } \\
\text { - In patients with Helicobacter pylori infection and/or existing/previous } \\
\text { stomach/peptic ulcers and/or dyspepsia } \\
\text { - By ASA and NSAID use and alcohol consumption }\end{array}$ & $\begin{array}{l}\text { - Prescribe proton pump inhibitors } \\
\text { - Treat for H. pylori } \\
\text { - Manage diet and alcohol intake } \\
\text { - Avoid concomitant use of NSAIDs and ASA unless indicated }{ }^{72}\end{array}$ \\
\hline \multicolumn{2}{|l|}{ Polypharmacy } \\
\hline $\begin{array}{l}\text { Concomitant use of P-gP and/or CYP3A4 inhibitors may lead to increased } \\
\text { DOAC plasma concentrations } \\
\text { Drug-drug interactions may increase the risk of falls }{ }^{40,73}\end{array}$ & $\begin{array}{l}\text { - Regular medicines management reviews should be performed } \\
\text { to ensure no contraindications or unnecessary medicine usage } \\
\text { and that the appropriate doses are being administered }\end{array}$ \\
\hline \multicolumn{2}{|l|}{ Lifestyle } \\
\hline $\begin{array}{l}\text { Poor adherence to anticoagulant therapy may increase the risk of bleeding } \\
\text { (ie, if the patient overdoses) } \\
\text { Drug and alcohol misuse may increase the risk of falls/trauma }{ }^{40}\end{array}$ & $\begin{array}{l}\text { - Patient communication and education may improve treatment } \\
\text { adherence } \\
\text { - Reduce the risk of substance misuse; refer patient for alcohol/ } \\
\text { drug dependency counseling }\end{array}$ \\
\hline \multicolumn{2}{|l|}{ Risk of falls } \\
\hline $\begin{array}{l}\text { Postural hypotension, visual impairment, reduced mobility/frailty, and } \\
\text { psychotropic medications (such as benzodiazepines, antidepressants, and } \\
\text { antipsychotics) and drug-drug interactions may be associated with an } \\
\text { increased risk of falls }{ }^{73,74}\end{array}$ & $\begin{array}{l}\text { - Check for low blood pressure to prevent dizziness and fainting } \\
\text { - Correct visual impairment } \\
\text { - Provide mobility aids such as walking sticks or handrails } \\
\text { - Reconsider need for any psychotropic medications } \\
\text { - Review medicine use regularly to optimize combinations }\end{array}$ \\
\hline
\end{tabular}

Abbreviations: AF, atrial fibrillation; ASA, acetylsalicylic acid; CYP3A4, cytochrome P450 3A4; DOAC, direct oral anticoagulant; NSAID, nonsteroidal anti-inflammatory drug; P-gp, P-glycoprotein. 


\section{Dosing considerations to minimize bleeding risk in patients treated with DOACs for stroke prevention}

Patient characteristics associated with increased bleeding risk can influence not only their suitability for a DOAC but also the prescribed dosing regimen. Characteristics increasing the risk of bleeding and influencing DOAC suitability include hepatic and renal impairment and certain concomitant medications; physicians need to be aware that the different
DOACs are contraindicated, not recommended or should be used with caution at differing degrees of hepatic and renal impairment, and with different concomitant medications (Table 4). ${ }^{43-46}$ Similarly, dependent on the DOAC, certain patient characteristics and certain concomitant medications can mandate the use of a reduced DOAC dose. ${ }^{43-46}$ For rivaroxaban, the reduced dose $(15 \mathrm{mg}$ od $)$ is only approved for use in patients with moderate or severe renal impairment, and all other patients, provided they have a creatinine clearance

Table 4 Recommendations for use and dosing regimens of the DOACs for stroke prevention in patients with nonvalvular atrial fibrillation according to patient characteristics and concomitant medications that may be associated with an increased risk of bleeding

\begin{tabular}{|c|c|c|c|c|}
\hline Recommended use & Dabigatran $^{45}$ & Rivaroxaban $^{43}$ & Apixaban ${ }^{44}$ & Edoxaban $^{46}$ \\
\hline Standard dose & $150 \mathrm{mg}$ bid & $20 \mathrm{mg}$ od to be taken with food & $5 \mathrm{mg}$ bid & $60 \mathrm{mg}$ od \\
\hline \multicolumn{5}{|c|}{ Patients with active bleeding } \\
\hline Contraindications & \multicolumn{4}{|c|}{$\begin{array}{l}\text { Active clinically significant bleeding or a lesion or condition considered to be a high risk for major bleeding (including } \\
\text { current or recent Gl ulceration, presence of malignant neoplasms at high risk of bleeding, recent CNS injury or surgery, } \\
\text { recent ICH, known or suspected esophageal varices, arteriovenous malformations, vascular aneurysms, or major } \\
\text { intracerebral or intraspinal abnormalities) }\end{array}$} \\
\hline \multicolumn{5}{|c|}{ Patients with hepatic impairment } \\
\hline Contraindications & $\begin{array}{l}\text { Hepatic impairment or liver } \\
\text { disease expected to have an } \\
\text { impact on survival }\end{array}$ & $\begin{array}{l}\text { Hepatic disease associated } \\
\text { with coagulopathy and clinically } \\
\text { relevant bleeding risk, including } \\
\text { cirrhotic patients with moderate- } \\
\text { to-severe hepatic impairment } \\
\text { (Child-Pugh B and C) }\end{array}$ & $\begin{array}{l}\text { Hepatic disease associated } \\
\text { with coagulopathy and } \\
\text { clinically relevant bleeding } \\
\text { risk }\end{array}$ & $\begin{array}{l}\text { Hepatic disease } \\
\text { associated with } \\
\text { coagulopathy and } \\
\text { clinically relevant } \\
\text { bleeding risk }\end{array}$ \\
\hline Not recommended & $\begin{array}{l}\text { Elevated liver enzymes } \\
(>2 \times \text { ULN) }\end{array}$ & NA & Severe hepatic impairment & $\begin{array}{l}\text { Severe hepatic } \\
\text { impairment }\end{array}$ \\
\hline Use with caution & NA & NA & $\begin{array}{l}\text { Mild or moderate hepatic } \\
\text { impairment (Child-Pugh A } \\
\text { or B) } \\
\text { Elevated liver enzymes } \\
\text { ALT/AST }>2 \times \text { ULN or total } \\
\text { bilirubin } \geq 1.5 \times \text { ULN }\end{array}$ & $\begin{array}{l}\text { Mild-to-moderate } \\
\text { hepatic impairment } \\
\text { Elevated liver enzymes } \\
\text { ALT/AST }>2 \times \text { ULN or } \\
\text { total bilirubin } \geq 1.5 \times \\
\text { ULN }\end{array}$ \\
\hline \multicolumn{5}{|c|}{ Patients with renal impairment } \\
\hline Dose adjustments & $\begin{array}{l}\text { A dose reduction to } 110 \mathrm{mg} \text { bid } \\
\text { should be considered in patients } \\
\text { with } \mathrm{CrCl} 30-49 \mathrm{~mL} / \mathrm{min} \text { and a } \\
\text { high risk of bleeding }\end{array}$ & $\begin{array}{l}15 \mathrm{mg} \text { od in patients with } \mathrm{CrCl} \\
15-49 \mathrm{~mL} / \mathrm{min}\end{array}$ & $\begin{array}{l}2.5 \mathrm{mg} \text { bid in patients with } \\
\geq 2 \text { of the following criteria: } \\
\text { age } \geq 80 \text { years, body } \\
\text { weight } \leq 60 \mathrm{~kg} \text {, serum } \\
\text { creatinine } \geq 1.5 \mathrm{mg} / \mathrm{dL} \\
(133 \mu \mathrm{mol} / \mathrm{L}) \\
2.5 \mathrm{mg} \mathrm{bid} \mathrm{in} \mathrm{patients} \mathrm{with} \\
\mathrm{CrCl} 15-29 \mathrm{~mL} / \mathrm{min}\end{array}$ & $\begin{array}{l}30 \mathrm{mg} \text { od in patients } \\
\text { with } \mathrm{CrCl} / 5-50 \mathrm{~mL} / \\
\text { min }\end{array}$ \\
\hline Contraindications & $\mathrm{CrCl}<30 \mathrm{~mL} / \mathrm{min}$ & NA & NA & NA \\
\hline Not recommended & NA & Patients with $\mathrm{CrCl}<15 \mathrm{~mL} / \mathrm{min}$ & $\begin{array}{l}\text { Patients with } \mathrm{CrCl} \\
<15 \mathrm{~mL} / \mathrm{min}\end{array}$ & $\begin{array}{l}\text { Patients with } \mathrm{CrCl} \\
<15 \mathrm{~mL} / \mathrm{min}\end{array}$ \\
\hline $\begin{array}{l}\text { Use with caution } \\
\text { Elderly patients }\end{array}$ & NA & Patients with $\mathrm{CrCl} 15-29 \mathrm{~mL} / \mathrm{min}$ & NA & NA \\
\hline Dose adjustments & $\begin{array}{l}\text { Age } \geq 80 \text { years: } 110 \mathrm{mg} \text { bid } \\
\text { In patients aged } 75-80 \text { years } \\
\text { a dose reduction to } 110 \mathrm{mg} \\
\text { bid may be considered when } \\
\text { thromboembolic risk is low } \\
\text { and bleeding risk is high }\end{array}$ & $\begin{array}{l}\text { No dose adjustment based on } \\
\text { age alone }\end{array}$ & $\begin{array}{l}2.5 \mathrm{mg} \text { bid in patients } \\
\text { with } \geq 2 \text { of the following } \\
\text { criteria: age } \geq 80 \text { years, } \\
\text { body weight } \leq 60 \mathrm{~kg} \text {, serum } \\
\text { creatinine } \geq 1.5 \mathrm{mg} / \mathrm{dL} \\
(\mid 33 \mu \mathrm{mol} / \mathrm{L})\end{array}$ & $\begin{array}{l}\text { No dose adjustment } \\
\text { based on age alone }\end{array}$ \\
\hline
\end{tabular}


Table 4 (Continued)

\begin{tabular}{|c|c|c|c|c|}
\hline & Dabigatran $^{45}$ & Rivaroxaban $^{43}$ & Apixaban ${ }^{44}$ & Edoxaban $^{46}$ \\
\hline \multicolumn{5}{|c|}{ Patients receiving concomitant P-gp or CYP3A4 inhibitors that increase DOAC plasma concentrations } \\
\hline Dose adjustments & $\begin{array}{l}\text { I } 10 \mathrm{mg} \text { bid in patients receiving } \\
\text { concomitant verapamil }\end{array}$ & $\begin{array}{l}\text { No dose adjustment based on } \\
\text { use of concomitant P-gp or } \\
\text { CYP3A4 inhibitors alone }\end{array}$ & $\begin{array}{l}\text { No dose adjustment based } \\
\text { on use of concomitant P-gP } \\
\text { or CYP3A4 inhibitors alone }\end{array}$ & $\begin{array}{l}30 \text { mg od in patients } \\
\text { receiving concomitant } \\
\text { cyclosporine, } \\
\text { dronedarone, } \\
\text { erythromycin, or } \\
\text { ketoconazole }\end{array}$ \\
\hline Contraindications & $\begin{array}{l}\text { Concomitant treatment } \\
\text { with systemic ketoconazole, } \\
\text { cyclosporine, itraconazole, } \\
\text { and dronedarone }\end{array}$ & NA & NA & NA \\
\hline Not recommended & $\begin{array}{l}\text { Concomitant treatment with } \\
\text { tacrolimus }\end{array}$ & $\begin{array}{l}\text { Concomitant systemic treatment } \\
\text { with azole antimycotics } \\
\text { (eg, ketoconazole, itraconazole, } \\
\text { voriconazole, and posaconazole) } \\
\text { or HIV protease inhibitors } \\
\text { (eg, ritonavir) } \\
\text { Coadministration with } \\
\text { dronedarone should be avoided }\end{array}$ & $\begin{array}{l}\text { Concomitant systemic } \\
\text { treatment with } \\
\text { azole-antimycotics } \\
\text { (eg, ketoconazole, } \\
\text { itraconazole, voriconazole, } \\
\text { and posaconazole) or HIV } \\
\text { protease inhibitors } \\
\text { (eg, ritonavir) }\end{array}$ & NA \\
\hline Use with caution & $\begin{array}{l}\text { Caution advised with } \\
\text { concomitant treatment } \\
\text { with amiodarone, quinidine, } \\
\text { posaconazole, verapamil, } \\
\text { clarithromycin, or ticagrelor, } \\
\text { especially in patients with mild- } \\
\text { to-moderate renal impairment }\end{array}$ & $\begin{array}{l}\text { Caution advised in patients with } \\
\text { renal impairment concomitantly } \\
\text { receiving clarithromycin, } \\
\text { erythromycin, or fluconazole }\end{array}$ & NA & NA \\
\hline \multicolumn{5}{|c|}{ Patients receiving concomitant treatment with drugs affecting hemostasis } \\
\hline Dose reductions & $\begin{array}{l}\text { Consider dose reduction to } \\
\text { I } 10 \text { mg bid in patients receiving } \\
\text { concomitant treatment with } \\
\text { clopidogrel, ASA, or NSAIDs, } \\
\text { especially if patient is } \geq 75 \text { years old }\end{array}$ & $\begin{array}{l}\text { No dose adjustment based on } \\
\text { use of drugs affecting hemostasis }\end{array}$ & $\begin{array}{l}\text { No dose adjustment based } \\
\text { on use of drugs affecting } \\
\text { hemostasis }\end{array}$ & $\begin{array}{l}\text { No dose adjustment } \\
\text { based on use of drugs } \\
\text { affecting hemostasis }\end{array}$ \\
\hline Not recommended & NA & NA & $\begin{array}{l}\text { Concomitant use of } \\
\text { thienopyridines } \\
\text { (eg, clopidogrel) or } \\
\text { dipyridamole }\end{array}$ & $\begin{array}{l}\text { Concomitant chronic } \\
\text { use of high-dose ASA } \\
(325 \mathrm{mg} / \mathrm{d}) \text { or NSAIDs }\end{array}$ \\
\hline Use with caution & $\begin{array}{l}\text { Concomitant administration } \\
\text { with drugs affecting hemostasis } \\
\text { by inhibition of platelet } \\
\text { aggregation }\end{array}$ & $\begin{array}{l}\text { Concomitant treatment with } \\
\text { NSAIDs, ASA, or platelet } \\
\text { aggregation inhibitors }\end{array}$ & $\begin{array}{l}\text { Concomitant administration } \\
\text { of NSAIDs or ASA }\end{array}$ & $\begin{array}{l}\text { Concomitant } \\
\text { administration of ASA in } \\
\text { elderly patients }\end{array}$ \\
\hline \multicolumn{5}{|c|}{ Other patients at increased risk of bleeding or elevated DOAC concentrations } \\
\hline Dose adjustments & $\begin{array}{l}\text { Consider dose reduction } \\
\text { to II0 mg bid in patients } \\
\text { with gastritis, esophagitis, or } \\
\text { gastroesophageal reflux and } \\
\text { in other patients at increased } \\
\text { risk of bleeding (eg, patients } \\
\text { receiving concomitant } \\
\text { treatment with SSRIs or SNRIs) }\end{array}$ & $\begin{array}{l}\text { No dose adjustments based on } \\
\text { bleeding risk alone }\end{array}$ & $\begin{array}{l}\text { No dose adjustments based } \\
\text { on bleeding risk alone }\end{array}$ & $\begin{array}{l}30 \mathrm{mg} \text { od in patients } \\
\text { with low body weight } \\
(\leq 60 \mathrm{~kg})\end{array}$ \\
\hline
\end{tabular}

Abbreviations: ALT, alanine aminotransferase; ASA, acetylsalicylic acid; AST, aspartate aminotransferase; bid, twice daily; CNS, central nervous system; CrCl, creatinine clearance; CYP3A4, cytochrome P450 3A4; DOAC, direct oral anticoagulant; GI, gastrointestinal; HIV, human immunodeficiency virus; ICH, intracranial hemorrhage; NA, not applicable; NSAID, nonsteroidal anti-inflammatory drug; od, once daily; P-gp, P-glycoprotein; SNRI, serotonin-norepinephrine reuptake inhibitor; SSRI, selective serotonin reuptake inhibitor; ULN, upper limit of normal. 
$>50 \mathrm{~mL} / \mathrm{min}$, are recommended to receive $20 \mathrm{mg}$ od. ${ }^{43}$ For the other DOACs (apixaban, edoxaban, and dabigatran), a patient's renal function, age, body weight, and concomitant medications may need to be considered to ensure selection of the correct dosing regimen to best balance ischemic and bleeding risks (Table 4). ${ }^{44-46}$

When considering use of a DOAC in a patient with a high HAS-BLED score, many physicians may wonder whether it is appropriate to prescribe a reduced-dose DOAC. In the case of the Factor Xa inhibitors apixaban and rivaroxaban, the lower doses are only approved in patients fulfilling certain criteria as tested in their respective Phase III clinical trials - and these did not include an elevated bleeding risk in the absence of factors specifically mandating a dose reduction (Tables 1 and 4). ${ }^{15,18,43,44}$ Consequently, there is no evidence to support the efficacy of apixaban $2.5 \mathrm{mg}$ bid or rivaroxaban $15 \mathrm{mg}$ od in patients not meeting the criteria for a dose reduction; therefore, a patient with a high bleeding risk (but no other factors mandating use of a reduced dose) should receive the higher approved dose of apixaban $(5 \mathrm{mg}$ bid) or rivaroxaban (20 mg od). ${ }^{43,44}$ In the RE-LY trial, patients treated with dabigatran were randomized to one of two dabigatran doses (110 $\mathrm{mg}$ bid or $150 \mathrm{mg}$ bid) and the results showed dabigatran $150 \mathrm{mg}$ bid to be superior to warfarin for the prevention of stroke or systemic embolism with a similar rate of major bleeding, whereas dabigatran $110 \mathrm{mg}$ bid was noninferior to warfarin for prevention of stroke or systemic embolism but associated with significant reductions in major bleeding. ${ }^{16,20}$ Based on these data, the European label suggests that, in patients with an increased bleeding risk (including those aged 75-80 years or with gastritis, esophagitis, or gastroesophageal reflux), a daily dose of $150 \mathrm{mg}$ bid or $110 \mathrm{mg}$ bid should be selected based on an individual assessment of a patient's thromboembolic and bleeding risks. ${ }^{45}$ In Canada, the product monograph for dabigatran recommends the use of the $110 \mathrm{mg}$ bid dabigatran dose in patients aged 75 years or older with one or more risk factor for bleeding. ${ }^{47}$ In ENGAGE-AF-TIMI 48 , patients treated with edoxaban were randomized to either edoxaban $60 \mathrm{mg}$ od or edoxaban $30 \mathrm{mg}$ od, and, in either arm, the dose was halved if patients met the criteria for dose reduction (Table 1). ${ }^{17}$ Although the lower dose of edoxaban was shown to be noninferior to warfarin for the prevention of stroke or systemic embolism, ${ }^{17}$ data in the European Medicines Agency public assessment report indicate that edoxaban $30 \mathrm{mg}$ od was inferior to warfarin for the prevention of ischemic stroke or systemic embolism (1.89\%/year vs $1.36 \%$ year; $P<0.0001$ ), was associated with a higher number of disabling strokes ( 82 vs 57 patients), and a greater number of patients experienced $\geq 2$ primary efficacy events ( 21 vs eight patients); moreover, analysis by HAS-BLED score did not identify a group of patients who would benefit from edoxaban $30 \mathrm{mg}$ od. ${ }^{48}$ Therefore, the available data do not support the use of a reduced dose of edoxaban ( $30 \mathrm{mg}$ od) in patients at high risk of bleeding but not fulfilling criteria for dose reduction, owing to the increased risk of thromboembolic events, and edoxaban $60 \mathrm{mg}$ od should be prescribed. ${ }^{46,48}$

\section{Bleeding management strategies and health care resource use}

There are a range of bleeding management strategies available for both VKA and DOACs (it should also be noted that the fatal bleeding rate was lower for DOACs vs warfarin in three pivotal trials). ${ }^{15-17}$ These vary in terms of suitability for different patient groups and treatment situations, and their costs also differ, impacting on treatment availability and choices.

Management of bleeding with anticoagulants can be achieved in a variety of ways, with some overlap between the approaches for VKAs and DOACs. These include treatment cessation, as well as more infrequently used measures such as reversal agents or administration of coagulation factors. ${ }^{49}$ Restoration of coagulation function after cessation of warfarin takes several days, and therefore, it is not suitable for rapid reversal. Coagulation factors are a third option; these can be administered in the form of prothrombinase complex concentrate (PCC), which is derived from plasma and contains clotting factors II, VII, IX, and X, and results in immediate warfarin reversal. However, as the effect wears off after 6-12 hours, guidelines advise a combination of vitamin K and PCC. ${ }^{50}$ Activated PCC (Factor VIII inhibitor bypassing activity) is derived from Factor VIII and has a similar profile to the one described earlier for PCC; both PCC and activated PCC carry a thrombotic risk. Fresh-frozen plasma can also be considered, but is not advised unless PCC is unavailable; recombinant Factor VIIa can be used with agents such as heparin and fondaparinux in instances of critical bleeding. ${ }^{49}$

For the DOACs, as described earlier, some patient groups may benefit from dose reductions to balance bleeding risk and treatment efficacy, although this is not appropriate for all patients or with all DOACs. Specific reversal agents are also a potential option: idarucizumab, a Fab fragment targeted specifically against dabigatran, ${ }^{51}$ has recently been approved for use in emergency surgery/urgent procedures and for lifethreatening or uncontrolled bleeding; the RE-VERSE AD trial showed complete reversal of dabigatran plasma levels within minutes. ${ }^{51}$ Andexanet alfa, a Factor Xa decoy targeted against Factor Xa inhibitors, ${ }^{52}$ and ciraparantag (PER977), 
which antagonize multiple anticoagulants (unfractionated and low molecular weight heparins, and all four DOACs), are currently in clinical development. ${ }^{53}$ PCC may be used, although it is unclear whether its reversal of DOAC action corresponds to improved clinical outcomes as much of the relevant data are from healthy volunteers, in vitro studies, and animal models. ${ }^{54,55}$ Activated Factor VIIa or Factor VIII inhibitor bypassing activity may also be considered; ${ }^{55}$ oral activated charcoal can be used to prevent further absorption if the dose has been administered within the previous 2 hours. ${ }^{49,56}$

Dose cessations or reductions are limited in terms of sensitivity, not appropriate for all patients, and may not offer the best cost-benefit balance owing to impacts on treatment effectiveness. Estimates from studies on warfarin reversal in hip replacement surgery have shown dose cessation to be the most expensive approach when direct costs arising during hospitalization are accounted for; ${ }^{57}$ low-dose PCC has also been shown to be cost effective for management of VKA-induced bleeding versus a variable high-dose strategy. ${ }^{58}$ However, a recent study suggests that management of dabigatran-associated major bleeding with dose cessation is as effective as or superior to drug withdrawal plus administration of red cell concentrates, plasma, or coagulation factor concentrates. ${ }^{59}$ Cessation alone is not sufficient when rapid reversal of anticoagulant action is needed. PCC is expensive in terms of unit costs and is associated with a risk of thrombogenicity and concerns around transmission of prions or pathogens originating from pooled plasma; however, cost-benefit modeling has shown it to be more cost effective than fresh-frozen plasma for warfarin reversal. ${ }^{60,61}$ Vitamin $\mathrm{K}$ is inexpensive, but has no clinical usefulness in situations requiring rapid warfarin reversal. ${ }^{62}$

The reversal agents for the DOACs are effective and have a rapid onset of action, but are associated with higher costs (cost of idarucizumab is $\sim \$ 3,500$ per dose). ${ }^{63}$ The costs have not yet been determined for andexanet alfa or ciraparantag, but they are likely to be similarly priced once approved. The high costs of these agents may therefore restrict their use in some hospitals or regions, and cost-benefit analyses will also need to be conducted versus other approaches such as the nonspecific reversal agent PCC.

\section{Preprocedural maintenance of anticoagulation and management of bleeding}

Another key consideration for physicians is anticoagulation use prior to surgical/invasive procedures: treatment interruption transiently exposes patients to an increased risk of thromboembolism, whereas continuing treatment increases the risk of surgical bleeding. ${ }^{64}$ Additionally, different anticoagulants require different approaches. VKAs take several days for their anticoagulant effects to diminish, ${ }^{63}$ whereas the DOACs have shorter half-lives, meaning that their anticoagulant effects abate more rapidly following treatment cessation (although this is impacted by factors such as renal impairment). ${ }^{56,65}$ Specific reversal agents are not yet approved for the Factor Xa inhibitors, creating difficulties for patients requiring urgent procedures. For urgent surgeries associated with a high risk of bleeding, nonspecific reversal agents, such as PCC, may be considered.

Thrombosis and bleeding risks must be assessed prior to surgery; higher thrombosis risk reduces the duration that anticoagulation can safely be stopped for, whereas a higher bleeding risk requires a longer period of treatment cessation. For those with transiently increased high risk of thrombosis, delaying elective surgery can allow continuation of anticoagulation treatment and the risk to return to baseline. ${ }^{66}$ Patients at low risk of bleeding may be suitable to continue anticoagulation treatment prior to surgery, depending on the nature of the procedure. ${ }^{66}$ For the reasons discussed earlier, timing of treatment interruption must also be considered depending on which therapy the patient is receiving. Algorithms are available to help address this often complex issue of perioperative anticoagulation. ${ }^{67,68}$ Bridging therapy with a fast-acting parenteral agent (eg, low molecular weight heparin) can be considered for patients at a very high risk of thromboembolism and receiving VKA, but is not necessary for most patients owing to the increased risk of bleeding and lack of impact on thromboembolic risk that has been reported in some studies. ${ }^{69}$

\section{Conclusion}

Bleeding risk is often a concern for physicians when considering the use of the DOACs in high-risk patients with nonvalvular AF. This concern may be heightened if the patient is elderly, has comorbidities, is prescribed many medications, or is perceived to be at high risk of falling. Proper assessment of bleeding risk and taking steps to minimize any modifiable risk factors, together with selection of the correct dose of DOAC for stroke prevention based on a patient's characteristics and concomitant medications, should reduce the risk of DOACassociated bleeding. These simple recommendations should give physicians greater confidence in the use of the DOACs, to optimize adequate protection against stroke.

\section{Acknowledgment}

The author would like to acknowledge Jo Luscombe and Robert Gillies, who provided editorial support with funding from Bayer. 


\section{Disclosure}

JSH has participated in speakers' bureaus or acted as a consultant for, and received honoraria from Bayer, Bristol-Myers Squibb, Pfizer, Boehringer, Lilly, Amgen, Novo-Nordisk, Astra-Zeneca, and Astellas, and reports no other conflicts of interest in this work.

\section{References}

1. Camm AJ, Kirchhof P, Lip GYH, et al. Guidelines for the management of atrial fibrillation: The Task Force for the Management of Atrial Fibrillation of the European Society of Cardiology (ESC). Eur Heart J. 2010; 31(19):2369-2429.

2. Wolf PA, Abbott RD, Kannel WB. Atrial fibrillation as an independent risk factor for stroke: the Framingham Study. Stroke. 1991;22(8):983-988.

3. Fang MC, Go AS, Chang Y, et al. Long-term survival after ischemic stroke in patients with atrial fibrillation. Neurology. 2014;82(12):1033-1037.

4. Palm F, Kraus M, Safer A, Wolf J, Becher H, Grau AJ. Management of oral anticoagulation after cardioembolic stroke and stroke survival data from a population based stroke registry (LuSSt). BMC Neurol. 2014;14:199.

5. McGrath ER, Kapral MK, Fang J, et al; Investigators of the Ontario Stroke Registry. Association of atrial fibrillation with mortality and disability after ischemic stroke. Neurology. 2013;81(9):825-832.

6. Marini C, De Santis F, Sacco S, et al. Contribution of atrial fibrillation to incidence and outcome of ischemic stroke: results from a populationbased study. Stroke. 2005;36(6):1115-1119.

7. van Walraven C, Hart RG, Singer DE, et al. Oral anticoagulants vs aspirin in nonvalvular atrial fibrillation: an individual patient meta-analysis. JAMA. 2002;288(19):2441-2448.

8. Bassand JP. Review of atrial fibrillation outcome trials of oral anticoagulant and antiplatelet agents. Europace. 2012;14(3):312-324.

9. Sen S, Dahlberg KW. Physician's fear of anticoagulant therapy in nonvalvular atrial fibrillation. Am J Med Sci. 2014;348(6):513-521.

10. Gage BF, Cardinalli AB, Owens DK. The effect of stroke and stroke prophylaxis with aspirin or warfarin on quality of life. Arch Intern Med. 1996; 156(16):1829-1836.

11. Devereaux PJ, Anderson DR, Gardner MJ, et al. Differences between perspectives of physicians and patients on anticoagulation in patients with atrial fibrillation: observational study. Br Med J. 2001;323(7323): 1218-1222.

12. Crowther MA, Warkentin TE. Bleeding risk and the management of bleeding complications in patients undergoing anticoagulant therapy: focus on new anticoagulant agents. Blood. 2008;111(10):4871-4879.

13. Gattellari M, Worthington J, Zwar N, Middleton S. Barriers to the use of anticoagulation for nonvalvular atrial fibrillation: a representative survey of Australian family physicians. Stroke. 2008;39(1):227-230.

14. Choudhry NK, Anderson GM, Laupacis A, Ross-Degnan D, Normand SL, Soumerai SB. Impact of adverse events on prescribing warfarin in patients with atrial fibrillation: matched pair analysis. Br Med J. 2006; 332(7534):141-145.

15. Patel MR, Mahaffey KW, Garg J, et al; ROCKET AF Investigators. Rivaroxaban versus warfarin in nonvalvular atrial fibrillation. $N$ Engl $\mathrm{J} \mathrm{Med}$. 2011;365(10):883-891.

16. Connolly SJ, Ezekowitz MD, Yusuf S, et al; RE-LY Steering Committee and Investigators. Dabigatran versus warfarin in patients with atrial fibrillation. $N$ Engl J Med. 2009;361(12):1139-1151.

17. Giugliano RP, RuffCT, Braunwald E, et al; ENGAGEAF-TIMI 48 Investigators. Edoxaban versus warfarin in patients with atrial fibrillation. N Engl J Med. 2013;369(22):2093-2104.

18. Granger CB, Alexander JH, McMurray JJ, et al; ARISTOTLE Committees and Investigators. Apixaban versus warfarin in patients with atrial fibrillation. N Engl J Med. 2011;365(11):981-992.

19. Connolly SJ, Ezekowitz MD, Yusuf S, Reilly PA, Wallentin L. Newly identified events in the RE-LY trial. NEngl J Med. 2010;363(19):1875-1876.

20. Connolly SJ, Wallentin L, Yusuf S. Additional events in the RE-LY trial. N Engl J Med. 2014;371(15):1464-1465.
21. Eikelboom JW, Wallentin L, Connolly SJ, et al. Risk of bleeding with 2 doses of dabigatran compared with warfarin in older and younger patients with atrial fibrillation: an analysis of the randomized evaluation of longterm anticoagulant therapy (RE-LY) trial. Circulation. 2011;123(21): 2363-2372.

22. Sherwood MW, Nessel CC, Hellkamp AS, et al. Gastrointestinal bleeding in patients with atrial fibrillation treated with rivaroxaban or warfarin: ROCKET AF trial. J Am Coll Cardiol. 2015;66(21):2271-2281.

23. Ruff CT, Giugliano RP, Braunwald E, et al. Comparison of the efficacy and safety of new oral anticoagulants with warfarin in patients with atrial fibrillation: a meta-analysis of randomised trials. Lancet. 2014; 383(9921):955-962.

24. Camm AJ, Amarenco P, Haas S, et al. XANTUS: a real-world, prospective, observational study of patients treated with rivaroxaban for stroke prevention in atrial fibrillation. Eur Heart J. 2016;37(14): $1145-1153$.

25. Tamayo S, Frank PW, Patel M, et al. Characterizing major bleeding in patients with nonvalvular atrial fibrillation: a pharmacovigilance study of 27467 patients taking rivaroxaban. Clin Cardiol. 2015;38(2): 63-68.

26. Villines TC, Schnee J, Fraeman K, et al. A comparison of the safety and effectiveness of dabigatran and warfarin in non-valvular atrial fibrillation patients in a large healthcare system. Thromb Haemost. 2015;114(6):1290-1298.

27. Graham DJ, Reichman ME, Wernecke M, et al. Cardiovascular, bleeding, and mortality risks in elderly Medicare patients treated with dabigatran or warfarin for non-valvular atrial fibrillation. Circulation. 2015;131(2):157-164.

28. Lauffenburger JC, Farley JF, Gehi AK, Rhoney DH, Brookhart MA, Fang G. Effectiveness and safety of dabigatran and warfarin in realworld US patients with non-valvular atrial fibrillation: a retrospective cohort study. J Am Heart Assoc. 2015;4(4):e001798.

29. Larsen TB, Gorst-Rasmussen A, Rasmussen LH, Skjoth F, Rosenzweig M, Lip GYH. Bleeding events among new starters and switchers to dabigatran compared with warfarin in atrial fibrillation. AmJMed.2014;127(7):650-656.

30. Larsen TB, Rasmussen LH, Skjøth F, et al. Efficacy and safety of dabigatran etexilate and warfarin in "real-world" patients with atrial fibrillation: a prospective nationwide cohort study. J Am Coll Cardiol. 2013; 61(22):2264-2273.

31. Chang HY, Zhou M, Tang W, Alexander GC, Singh S. Risk of gastrointestinal bleeding associated with oral anticoagulants: population based retrospective cohort study. BMJ. 2015;350:h1585.

32. Abraham NS, Singh S, Alexander GC, et al. Comparative risk of gastrointestinal bleeding with dabigatran, rivaroxaban, and warfarin: population based cohort study. BMJ. 2015;350:h1857.

33. Pisters R, Lane DA, Nieuwlaat R, de Vos CB, Crijns HJ, Lip GYH. A novel user-friendly score (HAS-BLED) to assess 1-year risk of major bleeding in patients with atrial fibrillation: the Euro Heart Survey. Chest. 2010;138(5):1093-1100.

34. Fang MC, Go AS, Chang Y, et al. A new risk scheme to predict warfarin-associated hemorrhage: the ATRIA (Anticoagulation and Risk Factors in Atrial Fibrillation) Study. J Am Coll Cardiol. 2011;58(4): 395-401.

35. O'Brien EC, Simon DN, Thomas LE, et al. The ORBIT bleeding score: a simple bedside score to assess bleeding risk in atrial fibrillation. Eur Heart J. 2015;36(46):3258-3264.

36. Camm AJ, Lip GYH, De Caterina R, et al. 2012 focused update of the ESC Guidelines for the management of atrial fibrillation: an update of the 2010 ESC Guidelines for the management of atrial fibrillation. Developed with the special contribution of the European Heart Rhythm Association. Eur Heart J. 2012;33(21):2719-2747.

37. National Institute for Health and Care Excellence. Atrial fibrillation: management. Clinical guideline 180; 2014. Available from: https:// www.nice.org.uk/guidance/cg180. Accessed May 6, 2016.

38. Patel AD, Tan MK, Angaran P, et al. Risk stratification and stroke prevention therapy care gaps in Canadian atrial fibrillation patients (from the Co-ordinated National Network to Engage Physicians in the Care and Treatment of Patients with Atrial Fibrillation chart audit). Am J Cardiol. 2015;115(5):641-646. 
39. Friberg L, Rosenqvist M, Lip GYH. Net clinical benefit of warfarin in patients with atrial fibrillation: a report from the Swedish atrial fibrillation cohort study. Circulation. 2012;125(19):2298-2307.

40. Lip GYH, Andreotti F, Fauchier L, et al. Bleeding risk assessment and management in atrial fibrillation patients: a position document from the European Heart Rhythm Association, endorsed by the European Society of Cardiology Working Group on Thrombosis. Europace. 2011; 13(5):723-746.

41. Man-Son-Hing M, Nichol G, Lau A, Laupacis A. Choosing antithrombotic therapy for elderly patients with atrial fibrillation who are at risk for falls. Arch Intern Med. 1999;159(7):677-685.

42. Gage BF, Birman-Deych E, Kerzner R, Radford MJ, Nilasena DS, Rich MW. Incidence of intracranial hemorrhage in patients with atrial fibrillation who are prone to fall. Am J Med. 2005;118(6):612-617.

43. Bayer Pharma AG. Xarelto ${ }^{\circledR}$ (rivaroxaban) Summary of Product Characteristics; 2015. Available from: http://www.ema.europa.eu/docs/en_GB/ document_library/EPAR_-_Product_Information/human/000944/ WC500057108.pdf. Accessed May 6, 2016.

44. Bristol-Myers Squibb, Pfizer. Eliquis ${ }^{\circledR}$ (apixaban) Summary of Product Characteristics; 2016. Available from: http://www.ema.europa. eu/docs/en_GB/document_library/EPAR_-_Product_Information/ human/002148/WC500107728.pdf. Accessed May 6, 2016.

45. Boehringer Ingelheim International GmbH. Pradaxa ${ }^{\circledR}$ (dabigatran etexilate) Summary of Product Characteristics; 2016. Available from: http:// www.ema.europa.eu/docs/en_GB/document_library/EPAR_-_Product_Information/human/000829/WC500041059.pdf. Accessed May 6, 2016.

46. Daiichi Sankyo Europe GmbH. Lixiana ${ }^{\circledR}$ (edoxaban) Summary of Product Characteristics; 2016. Available from: http://www.ema.europa. eu/docs/en_GB/document_library/EPAR_-_Product_Information/ human/002629/WC500189045.pdf. Accessed May 6, 2016.

47. Boehringer Ingelheim Canada Ltd. Pradaxa ${ }^{\circledR}$ (dabigatran etexilate capsules) Product Monograph; 2015. Available from: http://www. boehringer-ingelheim.ca/content/dam/internet/opu/ca_EN/documents/ humanhealth/product_monograph/PradaxaPMEN.pdf. Accessed March 21, 2016.

48. European Medicines Agency. Assessment report: Lixiana (Procedure No. EMEA/H/C/002629/0000); 2015. Available from: http://www. ema.europa.eu/docs/en_GB/document_library/EPAR_-_Public_assessment_report/human/002629/WC500189047.pdf. Accessed March 21, 2016.

49. Makris M,Van Veen JJ,TaitC, MumfordA,Laffan M, on behalf of the British Committee for Standards in Haematology. Guideline on the management of bleeding in patients on antithrombotic agents. Br J Haematol. 2012; 160(1):35-46.

50. Ansell J, Hirsh J, Hylek E, Jacobson A, Crowther M, Palareti G. Pharmacology and management of the vitamin $\mathrm{K}$ antagonists: American College of Chest Physicians evidence-based clinical practice guidelines (8th Edition). Chest. 2008;133(6 suppl):160S-198S.

51. Pollack CV Jr, Reilly PA, Eikelboom J, et al. Idarucizumab for dabigatran reversal. N Engl J Med. 2015;373(6):511-520.

52. Siegal DM, Curnutte JT, Connolly SJ, et al. Andexanet alfa for the reversal of Factor Xa inhibitor activity. N Engl J Med. 2015;373(25):2413-2424.

53. Ansell JE, Bakhru SH, Laulicht BE, et al. Use of PER977 to reverse the anticoagulant effect of edoxaban. $N$ Engl J Med. 2014;371(22): 2141-2142.

54. Dickneite G, Hoffman M. Reversing the new oral anticoagulants with prothrombin complex concentrates (PCCs): what is the evidence? Thromb Haemost. 2014;111(2):189-198.

55. Siegal DM. Managing target-specific oral anticoagulant associated bleeding including an update on pharmacological reversal agents. J Thromb Thrombolysis. 2015;39(3):395-402.
56. Heidbuchel H, Verhamme P, Alings M, et al. Updated European Heart Rhythm Association practical guide on the use of non-vitamin K antagonist anticoagulants in patients with non-valvular atrial fibrillation. Europace. 2015;17(10):1467-1507.

57. Purmonen T, Tormalehto S, Saavuori N, Kokki H. Budget impact analysis of warfarin reversal therapies among hip fracture patients in Finland. Drugs R D. 2015;15(1):155-162.

58. Khorsand N, Giepmans L, Meijer K, van Hest RM, Veeger NJ. A low fixed dose of prothrombin complex concentrate is cost effective in emergency reversal of vitamin K antagonists. Haematologica. 2013;98(6): e65-e67.

59. Majeed A, Hwang HG, Eikelboom JW, et al. Effectiveness and outcome of management strategies for dabigatran- or warfarin-related major bleeding events. Thromb Res. 2016;140:81-88.

60. Guest JF, Watson HG, Limaye S. Modeling the cost-effectiveness of prothrombin complex concentrate compared with fresh frozen plasma in emergency warfarin reversal in the United Kingdom. Clin Ther. 2010;32(14):2478-2493.

61. Hanley JP. Warfarin reversal. J Clin Pathol. 2004;57(11):1132-1139.

62. Watson HG, Baglin T, Laidlaw SL, Makris M, Preston FE. A comparison of the efficacy and rate of response to oral and intravenous vitamin $\mathrm{K}$ in reversal of over-anticoagulation with warfarin. Br J Haematol. 2001;115(1): $145-149$.

63. NEJM Journal Watch. Dabigatran Reversal Agent Price Set; 2015. Available from: http://www.jwatch.org/fw110754/2015/10/20/dabigatran-reversalagent-price-set. Accessed May 19, 2016.

64. Torn M, Rosendaal FR. Oral anticoagulation in surgical procedures: risks and recommendations. Br J Haematol. 2003;123(4):676-682.

65. Ieko M, Naitoh S, Yoshida M, Takahashi N. Profiles of direct oral anticoagulants and clinical usage-dosage and dose regimen differences. J Intensive Care. 2016;4:19.

66. Baron TH, Kamath PS, McBane RD. Management of antithrombotic therapy in patients undergoing invasive procedures. $N$ Engl J Med. 2013; 368(22):2113-2124.

67. Verma A, Cairns JA, Mitchell LB, et al; CCS Atrial Fibrillation Guidelines Committee. 2014 focused update of the Canadian Cardiovascular Society guidelines for the management of atrial fibrillation. Can J Cardiol. 2014;30(10):1114-1130.

68. Thrombosis Canada [webpage on the Internet]. Perioperative Anticoagulant Management Algorithm; 2016. Available from: http://thrombosiscanada.ca/?page_id=502\&calc=perioperativeAnticoagulantAlgorithm. Accessed May 19, 2016.

69. Douketis JD, Spyropoulos AC, Kaatz S, et al; BRIDGE Investigators. Perioperative bridging anticoagulation in patients with atrial fibrillation. N Engl J Med. 2015;373(9):823-833.

70. Fox KAA, Piccini JP, Wojdyla D, et al. Prevention of stroke and systemic embolism with rivaroxaban compared with warfarin in patients with non-valvular atrial fibrillation and moderate renal impairment. Eur Heart J. 2011;32(19):2387-2394.

71. DiMarco JP, Flaker G, Waldo AL, et al; AFFIRM Investigators. Factors affecting bleeding risk during anticoagulant therapy in patients with atrial fibrillation: observations from the Atrial Fibrillation Follow-up Investigation of Rhythm Management (AFFIRM) study. Am Heart J. 2005;149(4): 650-656.

72. Zullo A, Hassan C, Campo SM, Morini S. Bleeding peptic ulcer in the elderly: risk factors and prevention strategies. Drugs Aging. 2007;24(10): 815-828.

73. McMillan GJ, Hubbard RE. Frailty in older inpatients: what physicians need to know. QJM. 2012;105(11):1059-1065.

74. Hartikainen S, Lonnroos E, Louhivuori K. Medication as a risk factor for falls: critical systematic review.J GerontolA Biol Sci Med Sci. 2007;62(10): 1172-1181. 
The International Journal of General Medicine is an international, peer-reviewed open-access journal that focuses on general and internal medicine, pathogenesis, epidemiology, diagnosis, monitoring and treatment protocols. The journal is characterized by the rapid reporting of reviews, original research and clinical studies across all disease areas.
The manuscript management system is completely online and includes a very quick and fair peer-review system, which is all easy to use. Visit http://www.dovepress.com/testimonials.php to read real quotes from published authors. 